International Research Journal of Management, IT \& Social Sciences
Available online at https://sloap.org/journals/index.php/irjmis/
Vol. 6 No. 5, September 2019, pages: 167 174
ISSN: 2395-7492
https://doi.org/10.21744/irjmis.v6n5.712

\title{
Analysis of Impact Factors on Creative Manufacture Labor Absorption in Tenun Endek Creative Industry
}

\begin{tabular}{|c|c|}
\hline & $\begin{array}{c}\text { I Made Suantara } \\
\text { Made Henny Urmila Dewi }^{\mathrm{b}}\end{array}$ \\
\hline Article history: & Abstract \\
\hline $\begin{array}{l}\text { Received: } 09 \text { March } 2019 \\
\text { Accepted: } 31 \text { May } 2019 \\
\text { Published: } 28 \text { August } 2019\end{array}$ & $\begin{array}{l}\text { The thriving creative industry in Klungkung Regency is the Tenun Endek } \\
\text { industry. This study aims to analyze: 1) the direct effect of capital, wages, } \\
\text { investment and technology on the production in the Tenun Endek handicraft } \\
\text { industry in Klungkung Regency, 2) the direct effect of capital, wages, } \\
\text { investment, technology, and the production on labor in the Tenun Endek } \\
\text { handicraft industry in Klungkung Regency, 3) the indirect effect of capital, }\end{array}$ \\
\hline $\begin{array}{l}\text { Keywords: } \\
\text { capital; } \\
\text { creative industry; } \\
\text { labor; } \\
\text { production; } \\
\text { technology; }\end{array}$ & $\begin{array}{l}\text { Wages, investment, technology on labor absorption through the production in } \\
\text { the Tenun Endek handicraft industry in Klungkung Regency. The analytical } \\
\text { tool used is descriptive analysis, path analysis. The results showed that capital, } \\
\text { wages, investment, and technology had a significant positive effect on the } \\
\text { number of Tenun Endek handicraft industry production in Klungkung } \\
\text { Regency. Capital, wages, technology, total production have a significant } \\
\text { positive effect on labor. The investment has a significant negative effect on the } \\
\text { labor of endek woven handicraft industry workers in Klungkung Regency. } \\
\text { Capital, wages and technology have a significant positive effect on labor } \\
\text { through total production, while investment has a significant negative effect on } \\
\text { labor through total production. }\end{array}$ \\
\hline
\end{tabular}

2395-7492@ Copyright 2019. The Author. This is an open-access article under the CC BY-SA license (https://creativecommons.org/licenses/by-sa/4.0/) All rights reserved.

\section{Author correspondence:}

I Made Suantara,

Faculty of Economic and Business Udayana University, Denpasar, Indonesia.

Email address: mdsuantara.pekak@gmail.com

\section{Introduction}

The idea of a creative economy is believed to be able to mobilize people's creativity so that it becomes an important aspect that is capable of changing local economic conditions (Chapain \& Comunian, 2010; Foord, 2009). The creative economy presents the communication media and the cultural sector as priority locations for market growth and labor opportunities so that they can become centers of economic growth in general, both at the local and national level (Stam, de Jong \& Marlet, 2008; Peuter, 2011).

\footnotetext{
a Udayana University, Denpasar, Indonesia

${ }^{\mathrm{b}}$ Udayana University, Denpasar, Indonesia
} 
Indonesia has four industrial estates that have been recognized as creative zones, with a strong infrastructure foundation and industrial pillars, including; Bandung, Bali, DKI Jakarta, and Yogyakarta. The four regions are images or identities that serve as benchmarks for the development of creative industries in Indonesia.

Today, the creative economy is always crowded, especially after knowing how much the contribution of the creative economy industry such as art, music, fashion, and advertising to Indonesia's economic growth. The reason is that the creative economy industry is the result of the use of individual creativity, skills, and talents to create prosperity and labor by producing and exploiting individual creative and creative power. The creative economy industry is the basis of the character and symbol of the presence of the Indonesian people in the midst of interaction between nations in the world. By strengthening the structure of industry based on tradition and culture, intellectual property and cultural heritage of the nation can be preserved as a source of inspiration to produce new products that are high value-added and highly competitive and generally small and medium scale such as home industries (Santosa \& Sutarna, 2016).

Creative industries, related to the exploration of one's creativity to earn income, absorb jobs and improve welfare, have succeeded in making a significant contribution to the Indonesian economy both in terms of contributions to the Gross Domestic Product (GDP) Value, Labor Number, and Corporate Activity. The government is demanded to increasingly play a role in developing the Creative Industry in the future so that the Creative Industry can be used as a creative solution to alleviate poverty in Indonesia.

The creative industry is one of the important pillars in building the national economy. The reason, this industry is able to create competitive human resources in the era of globalization, as well as the welfare of the people of Indonesia. Bali Province is famous for its creative industries, where most Balinese people are involved in the creative industries. We know that the creative economy in Bali is developing very rapidly, one of which is in the creative industry.

Klungkung Regency, part of the Province of Bali, took the initiative to implement leading culture-based creative industry activities, especially in small industries as a strength of the local economy. According to the Ministry of Trade of the Republic of Indonesia (2009), so far in Bali Province, there are 4 sub-sectors of the creative economy that have the potential to be developed, namely: music, publishing and printing, crafts and fashion. Meanwhile, the Klungkung Regency Government through the Klungkung Regency Industry, Trade and Cooperatives Office formulated three potential subsectors that could develop, namely: the art, craft and fashion goods market.

Issues and issues that develop in the community that one of the factors that cause a decline in the value of production in the manufacturing industry include low market demand. The cause is that it is influenced by the qualities produced by the processing industry tend to be less desirable by the people of Bali and outside Bali. For example, woven cloth products such as endek which have been commodified (Gutierrez \& Moreira, 2018).

The ability of an economic sector including the industrial sector to absorb labor is reflected in the level of labor demand in companies that are members of an industrial group. Company demand for labor input is derived demand (derived demand) from consumer demand for the company's product (output). That is, the company's demand for labor is determined by consumer demand for company products. If the demand for firm output is large, then the demand for labor is also large. That's because entrepreneurs produce because they want to meet consumer demand.

Table 1

Top four industries and labors in Klungkung 2016-2017

\begin{tabular}{lllllc}
\hline & \multirow{2}{*}{ Type of Industry } & \multicolumn{2}{c}{ Unit off Industry } & \multicolumn{2}{c}{ Labor (Person) } \\
& $(2)$ & 2016 & 2017 & 2016 & 2017 \\
\hline$(1)$ & Tenun Endek & $(3)$ & $(4)$ & $(5)$ & $(6)$ \\
1 & 63 & 96 & 1.272 & 1.391 \\
2 & Metal Craft & 128 & 125 & 1.005 & 993 \\
3 & Food and Beverage & 55 & 68 & 317 & 379 \\
4 & Wood Craft & 30 & 25 & 373 & 286 \\
\hline
\end{tabular}

Source: Klungkung Regency Industry and Labor Office

Table 1 shows the number of industry and labor in industries that have the potential to be developed into creative industries. The textile industry, especially the Tenun Endek creative industry in Klungkung Regency in 2016 to 2017 showed the highest increase, compared to other industries in terms of the number of businesses. While in terms of labor, the Tenun Endek industry shows the highest position of the number of workers absorbed.

Seeing the role of the creative industry sector, especially the handicraft sub-sector producing endek woven cloth so large on labor, then the industry has great potential to be developed. If properly developed, this sub-sector will promise 
wider labor opportunities, so it is necessary to analyze the factors that affect labor in the Tenun Endek handicraft industry in Klungkung Regency.

Tenun endek is one of the local cultural heritages which is a superior product in Klungkung Regency. To lift this superior product, the Klungkung Regency Government through the Klungkung Regency Industry and Manpower Office, actively carries out various activities including workshops, seminars, fashion shows, and various other activities. The development of the endek woven industry in Klungkung Regency is certainly expected to increase the contribution of the industrial sector, especially the creative industries, to the GRDP. Besides that, the Tenun Endek industry is also strengthened by distribution stores that offer Tenun Endek handicrafts produced by local brands (Suluh Bali, 2013).

Considering that the development of creative industries that are starting to absorb labor, especially the endek woven handicraft industry in Klungkung Regency, it is very important to know what factors influence labor in the endek industry in Klungkung Regency. By knowing these factors, the government can begin to develop the industrial sector which will later be able to increase labor so as to reduce unlabor (Santosa \& Sutarna, 2016).

\section{Materials and Methods}

The research method used in this study is quantitative, using primary data obtained from respondents using questionnaires. The population consists of 96 business units. The technique of determining the sample using stratified random sampling. With an error rate of $10 \%$ and calculated using the Slovin formula, the samples to be studied amounted to 77 units of Tenun Endek handicraft industry in Klungkung Regency. The data analysis technique used is path analysis.

The conceptual framework of this study is as follows:

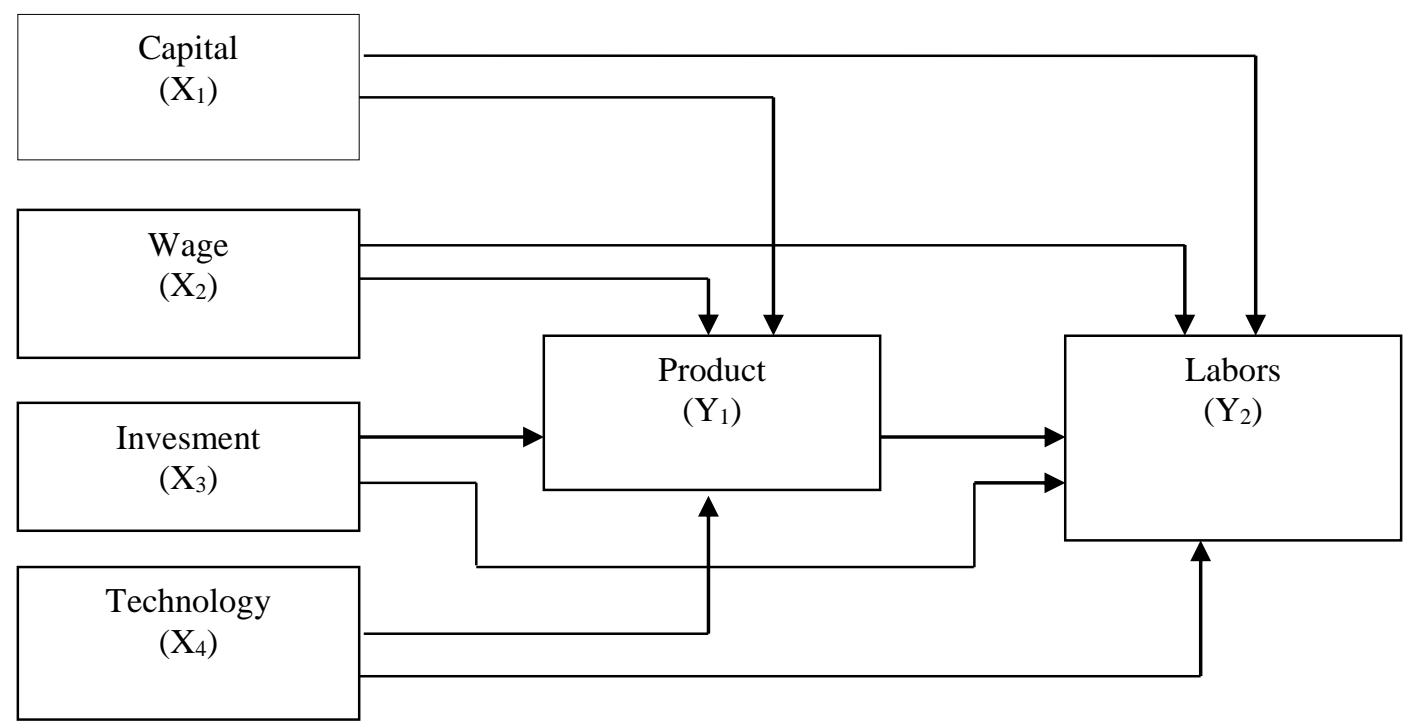

Figure 1. Conceptual framework

\section{Results and Discussions}

\section{Evaluation of Path Analysis}

In the path analysis model, the relationship between variables is linear and additive. Linearity test uses curve fit and applies the parsimony principle that is if the model is significant or non-significant it means that the model is linear.

Suantara, I. M., \& Dewi, M. H. U. (2019). Analysis of impact factors on creative manufacture labor absorption in tenun endek creative industry. International Research Journal of Management, IT and Social Sciences, 6(5), 167174. https://doi.org/10.21744/irjmis.v6n5.712 
Table 2

Linearity test

\begin{tabular}{llll}
\hline Variable & R-Square & F & Sig \\
\hline X1 -> Y1 & 0,813 & 326,695 & 0,000 \\
X2 -> Y1 & 0,770 & 251,725 & 0,000 \\
X3 - Y1 & 0,748 & 222,315 & 0,000 \\
X4 -> Y1 & 0,370 & 44,132 & 0,000 \\
X1 -> Y2 & 0,836 & 383,037 & 0,000 \\
X2 -> Y2 & 0,863 & 472,548 & 0,000 \\
X3 -> Y2 & 0,614 & 119,371 & 0,000 \\
X4 -> Y2 & 0,342 & 39,049 & 0,000 \\
Y1-> Y2 & 0,815 & 330,121 & 0,000 \\
\hline
\end{tabular}

Primary Data, 2018

The result shown by the significance less than 0.05 and the most linear relationship is X1-> Y2 by the F test is 383,037.

\section{Evaluation of Model Validity}

The validity of the structural model can be seen from the R2 value of the dependent variable. The R2 value of the dependent variable in this study is presented in Table 3.

Table 3

Model Validity Evaluation Testing Result

\begin{tabular}{lllll}
\hline No. & Dependent & Independent & R Square & Description \\
\hline 1 & $\mathrm{Y} 1$ & $\mathrm{X} 1, \mathrm{X} 2, \mathrm{X} 3, \mathrm{X} 4$ & 0,861 & Strong \\
2 & $\mathrm{Y} 2$ & $\mathrm{X} 1, \mathrm{X} 2, \mathrm{X} 3, \mathrm{X} 4, \mathrm{Y} 1$ & 0,925 & Strong \\
\hline
\end{tabular}

Primary Data, 2018

In this study, there are two dependent variables, namely the production (Y1) and labors (Y2). For the two dependent variables, the independent variable gives a value of $\mathrm{Y} 1$ gives a value of 0.861 so that the independent variable on the dependent variable is classified as strong. While the income level variable (Y2) gives a value of 0.925 so that the independent variable on the dependent variable is classified as strong.

\section{Direct Effect}

To find out the direct effect between construct variables can be seen from the results of the processed data with the path coefficients values shown in Table 4 .

Table 4

Path Coefficient

\begin{tabular}{lllll}
\hline Correlation & Coefficient & Standard & P-Value & Descirption \\
\hline X1 -> Y1 & 0,315 & 1,965 & 0,033 & Significant \\
X2 -> Y1 & 0,297 & 4,175 & 0,021 & Significant \\
X3 -> Y1 & 0,246 & 5,100 & 0,012 & Significant \\
X4 -> Y1 & 0,170 & 54,152 & 0,002 & Significant \\
X1 -> Y2 & 0,246 & 0,039 & 0,030 & Significant \\
X2 -> Y2 & 0,596 & 0,083 & 0,000 & Significant \\
X3 -> Y2 & $-0,294$ & 0,102 & 0,000 & Significant \\
X4 -> Y2 & 0,129 & 1,104 & 0,003 & Significant \\
Y1 -> Y2 & 0,334 & 0,002 & 0,000 & Significant \\
\hline
\end{tabular}

Primary Data, 2018 
Based on Table 4 it can be explained that capital has a positive and significant effect on the production which means the hypothesis is accepted. This is indicated by a path coefficient of 0.315 and a significance level of less than 0.05 , with a P-value of 0.033 . This means that the higher the capital, the higher the production.

Wages have a positive and significant effect on the production which means the hypothesis is accepted. This is indicated by a path coefficient of 0.297 and a significance level of less than 0.05 , with a P-value of 0.021 . This means that the higher the wage received by labor, the higher the production.

Investment has a positive and significant effect on the production which means the hypothesis is accepted. This is indicated by the path coefficient of 0.246 and a significance level of less than 0.05 , with a P-value of 0.012 . This means that the higher the level of investment in the Tenun Endek industry in Klungkung Regency, the production in the industry will also increase.

Modern technology produces more production compared to simple technology. This is indicated by a path coefficient of 0.170 and a significance level below 0.05 with a P-value of 0.002 . The data of the research results of respondents who use modern technology have more production than those who use simple technology, but there are still many respondents in the endek industry in Klungkung Regency who use simple technology with a smaller production.

Capital has a positive and significant effect on labor, which means the hypothesis is accepted. This is indicated by a coefficient value of 0.246 and a significance level of less than 0.05 with a P-value of 0.030 . This means that the higher the capital, the absorption rate of labor in the Tenun Endek industry in Klungkung Regency will increase.

Wages have a positive and significant effect on labor, which means the hypothesis is accepted. This is indicated by a coefficient value of 0.596 and a significance level of less than 0.05 with a P-value of 0,000 . This means that the higher wages, the level of labor in the Tenun Endek industry in Klungkung Regency will increase.

Investment has a negative and significant effect on labor, which means the hypothesis is rejected. This is indicated by a coefficient value of -0.294 and a significance level of less than 0.05 with a P-value of 0.000 . This means that the higher the investment, the rate of labor in the Tenun Endek industry in Klungkung will decrease.

Modern technology in the Tenun Endek industry absorbs higher labor than industries that still use simple technology. Judging from the coefficient of 0.129 with a significance level below 0.05 and a $\mathrm{P}$-value of 0.003 . This means that the Tenun Endek industry that uses modern technology in Klungkung Regency absorbs more labor compared to the Tenun Endek industry that uses simple technology.

The production has a positive and significant effect on labor, which means the hypothesis is accepted. This is indicated by a coefficient value of 0.334 and a significance level of less than 0.05 with a P-value of 0,000 . This means that the higher the production, the labor rate in the Tenun Endek industry in Klungkung Regency will increase.

\section{Indirect Effect}

The results of testing the indirect effect between the variables of capital, wages, investment, technology on labor absorption by mediating the production partially.

Table 5

Indirect Effect

\begin{tabular}{llllll}
\hline Exogenous & Mediation & Endogenous & Probability of Mediation & Probability of Endogenous & Description \\
\hline Capital & Production & Labors & 0,033 & 0,030 & Significant \\
Wage & Production & Labors & 0,021 & 0,000 & Significant \\
Investment & Production & Labors & 0,012 & 0,000 & Significant \\
Technology & Production & Labors & 0,002 & 0,003 & Significant \\
\hline
\end{tabular}

Primary Data, 2018

In Table 5 it can be seen that partially the number of production variables mediates capital, wages, investment and technology to labor in the Tenun Endek handicraft industry in Klungkung district which can be seen from the probability value of less than alpha 0.05 .

Suantara, I. M., \& Dewi, M. H. U. (2019). Analysis of impact factors on creative manufacture labor absorption in tenun endek creative industry. International Research Journal of Management, IT and Social Sciences, 6(5), $167-$ 174. https://doi.org/10.21744/irjmis.v6n5.712 
Based on the results of the analysis show capital has a positive and significant effect on the amount of Tenun Endek industry production in Klungkung Regency. This means that the higher the level of capital of a company, the level of use of production factors will be more, for example, the use of machinery, labor and inputs or raw materials. Increased production factors that are used will cause an increase in output or production of a company, and vice versa, if the capital used is small, then the use of production factors will be less and will affect the resulting production (Arsha, 2013).

Based on the results of the analysis shows that wages have a positive and significant effect on the quantity of Tenun Endek in Klungkung, this means that the hypothesis is accepted. Nini (2000), states that the high and low costs of company products are influenced by the level of wages of the labor. An increase in the wage level will result in an increase in production costs, thereby increasing the price per unit of product produced.

Based on the results of the analysis show that investment has a positive and significant effect on the amount of Tenun Endek industry production in Klungkung Regency, this means that the hypothesis is accepted. Investment in an industry is defined as expenditures made by investors (investors) involving the use of resources such as equipment, buildings, production equipment, other new machines or inventories that are expected to benefit from investment (Wiranata, 2004).

Based on the results of the analysis show that technology has a positive and significant effect on the amount of Tenun Endek industry production in Klungkung Regency, this means that the hypothesis is accepted. The results show that with more sophisticated technology, the results will also be better which will increase the production in an industry. The use of technology in production for companies aims to speed up the production process and fulfill large orders. A company that has large scale orders tends to use modern technology in its production process (Wijaya, 2013).

Based on the results of the analysis shows that the production partially mediates the effect of capital on the absorption of Tenun Endek industry workers in Klungkung Regency, so it can be interpreted that capital has an indirect effect on employment. The results of this study are supported by research conducted by Febriana Putri (2017), which shows that capital has a positive and significant direct effect on employment, meaning that if there is an increase in capital, the labor of the brick-making industry will increase.

Based on the results of the analysis shows that the production partially mediates the effect of wages on the absorption of labor in the Tenun Endek industry in Klungkung Regency, so it can be interpreted that wages have an indirect effect on employment. The Waisgrais (2003), found that wage policies produced a positive effect in terms of reducing the wage gap that occurred in the labor market.

Based on the results of the analysis shows that the production partially mediates the effect of investment on the absorption of Tenun Endek industry workers in Klungkung Regency, so it can be interpreted that investment has an indirect effect on employment. In Keynes's theory, the amount of investment made does not depend on the high or low-interest rates but depends on the size of the income received. The higher the income received, the greater the investment made.

Based on the results of the analysis shows that the production partially mediates the effect of technology on the absorption of labor in the Tenun Endek industry in Klungkung Regency, so it can be interpreted that technology has an indirect effect on labor absorption. The relationship between technology and labor absorption where when the industry has modern and sophisticated technology in its production, the labor needed is small because technology can replace jobs that cannot be done by human work and vice versa (Trian Arissana \& Sri Budhi 2016).

\section{Conclusion}

Capital, wages, investment, and technology have a positive and significant effect on the production in the Tenun Endek industry in Klungkung Regency. Capital, wages, technology, and production have a positive and significant effect on labor in the Tenun Endek industry in Klungkung district. Investment has a negative and significant effect on labor in the Tenun Endek industry in Klungkung Regency. 3) The production mediates the effect of capital, wages, investment and technology on labor of Tenun Endek industry workers in Klungkung Regency.

\section{Suggestion}

The government is expected to continuously give attention and guidance to entrepreneurs / Tenun Endek industry players so that the achievements that have been achieved can be maintained by facilitating training in the community and facilitating capital assistance to home-based businesses from small industries. Entrepreneurs are expected to be 
able to maintain the current achievements by managing their company as much as possible in managing capital, production, manpower absorbed and the technology used so that the products produced are optimal and can compete with other industries. Entrepreneurs are also expected to further promote endek woven products through print media, electronic media, and social media in order to attract local or foreign consumers to foreign countries.

\section{Conflict of interest statement}

The authors declared that they have no competing interest.

\section{Statement of authorship}

The authors have a responsibility for the conception and design of the study. The authors have approved the final article.

\section{Acknowledgments}

The authors would like to thank the editor of IRJMIS for their valuable time, support, and advice in completing the present research.

Suantara, I. M., \& Dewi, M. H. U. (2019). Analysis of impact factors on creative manufacture labor absorption in tenun endek creative industry. International Research Journal of Management, IT and Social Sciences, 6(5), $167-$ 174. https://doi.org/10.21744/irjmis.v6n5.712 


\section{References}

Chapain, C., \& Comunian, R. (2010). Enabling and inhibiting the creative economy: The role of the local and regional dimensions in England. Regional studies, 44(6), 717-734. https://doi.org/10.1080/00343400903107728

De Peuter, G. (2011). Creative economy and labor precarity: A contested convergence. Journal of communication inquiry, 35(4), 417-425. https://doi.org/10.1177\%2F0196859911416362

Departemen Perdagangan Republik Indonesia. (2009). Studi Industri Kreatif Indonesia.

Foord, J. (2009). Strategies for creative industries: an international review. Creative Industries Journal, 1(2), 91-113.

Gutierrez, R. B. O., \& Moreira, L. M. Z. (2018). The profile of executive secretaries and their relationship with labor demands. International Journal of Social Sciences and Humanities, $2(1), \quad 75-83$. https://doi.org/10.29332/ijssh.v2n1.84

Nata, K. S., \& Arsha, I. M. R. M. (2013). Pengaruh Tingkat Upah, Tenaga Kerja dan Modal Kerja terhadap Produksi Industri Pakaian Jadi Tekstil di Kota Denpasar. E-Jurnal Ekonomi Pembangunan Universitas Udayana, 2(8).

Putri, A. F., \& Kesumajaya, I. W. W. (2017). Analisis Pengaruh Modal, Tingkat Upah dan Teknologi terhadap Penyerapan Tenaga Kerja Serta Produksi pada Industri Kerajinan Batako di Kecamatan Mengwi Kabupaten Badung. E-Jurnal Ekonomi Pembangunan Universitas Udayana, 6(3).

Santosa, I. G., \& Sutarna, I. N. (2016). Workload evaluation towards the dodol workers from dryer section in Buleleng Bali. International Research Journal of Engineering, IT \& Scientific Research, 2(11), 66-74.

Santosa, I. G., \& Sutarna, I. N. (2016). Workload evaluation towards the dodol workers from dryer section in Buleleng Bali. International Research Journal of Engineering, IT \& Scientific Research, 2(11), 66-74.

Stam, E., De Jong, J. P., \& Marlet, G. (2008). Creative industries in the Netherlands: Structure, development, innovativeness and effects on urban growth. Geografiska Annaler: series B, human geography, 90(2), 119-132. https://doi.org/10.1111/j.1468-0467.2008.00282.x

Suluh Bali. (2013). Denpasar: Menjamurnya Bisnis Distro. Denpasar. Bali.

Waisgrais, S. (2003). Wage inequality and the labour market in Argentina: Labour institutions, supply and demand in the period 1980-1999. International Institute for Labour Studies, Discussion Paper DP/146.

Wijaya, T. (2013). Metodologi Penelitian Ekonomi dan Bisnis Teori dan Praktik. Yogyakarta: Graha Ilmu.

Wiranata, S. (2004). Pengembangan Investasi di Era Globalisasi dan Otonomi Daerah. Jurnal Ekonomidan Pembangunan, 12(1).

Yang, N., Chen, C. C., Choi, J., \& Zou, Y. (2000). Sources of work-family conflict: A Sino-US comparison of the effects of work and family demands. Academy of Management journal, 43(1), 113-123. https://doi.org/10.5465/1556390

Yeni, A., Triani, N., Budhi, S., \& Kembar, M. (2016). Analisis Faktor-faktor yang Mempengaruhi Penyerapan Tenaga Kerja dan Produktivitas Kerja Patung Kayu. E-Jurnal Ekonomi Pembangunan Universitas Udayana, 5(4). 